\title{
CORRECTIONS
}

\section{Publisher Correction: Locus-specific chromatin isolation}

\section{Michiel Vermeulen (1) and Jérôme Déjardin (1)}

Nature Reviews Molecular Cell Biology (2020) https://doi.org/10.1038/s41580-020-0217-0 Published online 29 January 2020

The original text included a typo in the example of length of a gene promoter or enhancer (' $300 \mathrm{~kb}$ ', instead of the correct ' $3 \mathrm{~kb}$ '). The mistake has been corrected in the html and PDF versions of the article.

https://doi.org/10.1038/s41580-020-0222-3 I Published online 3 February 2020

(c) Springer Nature Limited 2020 